УДК 94(=161.2):343.819.5(430)«1915/1917»]:37

DOI $10 / 15421 / 312005$

\author{
I. В. Срібняк \\ Київський університет імені Бориса Грінченка \\ М. Г. Паліснко \\ Київський начіональний університет \\ імені Тараса Шевченка
}

\title{
НАРОДНА ШКОЛА ГРАМОТИ В ТАБОРІ ПОЛОНЕНИХ УКРАЇНЦІВ ВЕЦЛЯР, НІМЕЧЧИНА (ВЕРЕСЕНЬ 1915 - БЕРЕЗЕНЬ 1917 РР.): КОРОТКИЙ НАРИС ІСТОРІЇ СТВОРЕННЯ ТА ДІЯЛЬНОСТІ
}

Срібняк І. В., Паліснко М. Г. Народна школа грамоти в таборі полонених украӥнців Вецляр, Німеччина (вересень 1915 - березень 1917 рр.): короткий нарис історї̈ створення та діяльності.

Проаналізовано специфіку функціонування народної школи у Вецлярі - таборі полонених українщів зі складу царської армії, визначено етапи ії розвитку. Встановлено, що починаючи з листопада 1916 р., народна школа стала «центром тяжіння» в масштабах усього табору, кількість ії учнів невпинно зростала, бо останні збагнули конечну потребу власної освіти. Розкрито заходи української організації табору із заміщення вчительських посад у школі та специфіку участі у викладацькій роботі цивільних членів таборового просвітнього відділу СВУ. Доведено, що завдяки народнін̆ пкколі полонені не тільки набували грамотності, вміння писати і рахувати, але й разом з тим в їх свідомості відбувалися незворотні зміни, що були зумовлені національним характером пкколи та патріотично-державницькою позицісю їі вчителів.

Ключові слова: полонені українці, народна школа, абетка, вчитель, учень, табір Вецляр, Німеччина.

Срибняк И. В., Палиенко М. Г. Народная школа грамоты в лагере военнопленных украинцев Вецляр, Германия (сентябрь 1915 - март 1917 гг.): короткий очерк истории создания и деятельности.

Проанализирована специфика функционирования народной школы в Вецляре - лагере военнопленных украинцев из состава царской армии, определены этапы её развития. Установлено, что, начиная с ноября 1916 г., народная пккола стала «центром притяжения» в масптабах всего лагеря, количество её учеников неуклонно возрастало, так как последние осознали конечную цель получения знаний. Раскрыты усилия украинской организации лагеря по замещению учительских должностей в школе и специфика участия в преподавательской работе гражданских членов лагерного просветительского отдела СВУ. Доказано, что, благодаря народной школе, военнопленные не только постигали грамоту и умение писать и считать, но вместе с тем в их сознании происходили необратимые изменения, обусловленные национальным характером шкколы и последовательной патриотической позицией её учителей.

Ключевые слова: украинцы-военнопленные, народная школа, азбука, учитель, ученик, лагерь Вецляр, Германия.

Sribnjak I. V., Palijenko M. G. Volksschule für Alphabetisierung im ukrainischen Kriegsgefangenenlager Wetzlar, Deutschland (September 1915 - März 1917): kurzer Überblick über die Geschichte und die Tätigkeit der Schule.

Es wurde die Spezifik des Funktionierens im Lager Wetzlar der Volksschule für gefangene Ukrainer aus der zaristischen Armee analysiert und die Etappen ihrer Entwicklung festgelegt. Es wurde festgestellt, dass die Volksschule ab November 1916 zum «Schwerpunkt» des ganzen Lagers geworden ist und die Zahl ihrer Schüler stetig gestiegen ist, weil die Letzteren den akuten Bedarf an eigener Bildung erkannt haben. Es wurden Maßnahmen zum Ersatz von Lehrstellen in der Schule und die Besonderheiten der Teilnahme der zivilen Mitglieder des Lagers aus der «Bildungsabteilung des Bundes für die Befreiung der Ukraine» an der Lehrtätigkeit beleuchtet. Es wurde bewiesen, dass die Gefangenen dank der Volksschule nicht nur Alphabetisierung, Schreib- und Zählfähigkeit erlangten, sondern auch dass sich ihr Bewusstsein total änderte, was auf den nationalen Charakter der Schule und die patriotische Position ihrer Lehrkräfte zurückzuführen ist.

Schlüsselwörter: ukrainische Kriegsgefangene, Volksschule, Alphabet, Lehrer, Schüler, Lager Wetzlar, Deutschland. 
Sribnyak I. V., Paliienko M. G. Literacy Training Public School in the Wetzlar Camp for the Ukrainian Prisoners of War, Germany (September 1915 - March 1917): a brief sketch of the establishment and activity

The article analyzes the specifics of the functioning of the public school in the Wetzlar Camp of Ukrainian prisoners of war who served in the tsarist army. The authors also identify the impact of education on the prisoners. Although the school was an effective tool of the Ukrainization processes, its influence was limited by strong anti-Ukrainian obstruction by the Black Hundred groups' members and the Little Russians during September 1915 October 1916. They were kept in the camp for many months. Nevertheless, the teaching staff of the school did not stop their work, contributing into the formation of national consciousness of their Ukrainian students. In the autumn of 1916, the efforts of the local Ukrainian clubs and institutions (including the public school) brought about a cumulative effect - most campers had adhered pro-Ukrainian views and begun actively participate im the activity of camp cultural and educational centres. This way the public school became a kind of "centre of gravity» throughout the camp and the number of its students grew steadily. It happened because the prisoners realized the ultimate need for their own education. They wanted to get rid of their illiteracy and acquired additional primary knowledge from various subjects offered to them by the school. The teachers staff were the civilian members of the Educational Department of the "Union for the Liberation of Ukraine". Thanks to them, the prisoners had the opportunity to learn Ukrainian literature, as well as get some knowledge in history and geography of Ukraine, arithmetic and science. Thus, because of the public school, the prisoners not only acquired literacy, got writing and grounding in mathematics, but they also broaden their minds. The irreversible changes im their national character happened due to the education and consistent patriotic position of the teachers. After visiting school, most of students were already mextricably linked to Ukraine, ready to share their knowledge to affirm national ideals among the Ukrainians.

Key words: Ukrainians - prisoners of war, public school, alphabet, teacher, student, Wetzlar camp, Germany.

Постановка проблеми. Одним з наслідків військових поразок царської армії на фронтах Першої світової війни стало потрапляння до німецького полону сотень тисяч їі вояків, які розмішувались у багатонаціннальних таборах. Значну частину 3 ïx числа становили мешканщі україиських губерній Російської імперії, які у переважній більшості були українцями за походженням. Прагнучи послабити Росію й у позавійськовий спосіб - шляхом внесення розколу в імперську єдність поневолених царатом народів, уряд Німеччини санкціонував створення національних таборів, зокрема й для полонених українців. Одним з таких таборів став Вецляр, украйнізація якого була здійснена заходами Берлінської централі (представництва) Союзу визволення України(СВУ) - безпартійної політичної організації українських емігрантів, що була створена у серпні 1914 p.

Аналіз наукових досліджень i публікацій. Окремі аспекти процесу становлення та розвитку просвітницыких організапій у таборі полонених україиців Вецляр (Німеччина) під час Першої світової війни вже вивчалися кількома німецькими [20; 21 ; 22] та українськими дослідниками [8; 9]. У 1999 р. побачив світ окремий нарис про цей табір (у межах монографічного дослідження), в якому було цілісно реконструйовано процес утворення та діяльності української організації у Вецлярі [10]. У ньому було синтезовано знач- ний обсяг матеріалу про специфіку діяльності освітніх організацій у цьому таборі.

Додаткову інформацію про цей табір (зокрема й розрізнені дані про освітнє життя таборян) було наведено в низці німецькомовних статей, що вийшли друком на початку XXI ст. [18; 19; 23]. Українські дослідники також виявили своє зацікавлення різними аспектами таборового повсякдення полонених українців у Вецлярі. Так, зокрема, особливості культурно-просвітньої роботи в українських таборах у Німеччині (й у Вецлярі) досліджувалися Л. Кривошеєвою [3, арк. 84-88]. Коротка згадка про участь Б. Лепкого у роботі народної школи у Вецлярі міститься в статті Н. Білик [1, с. 36-37].

Ця проблематика привернула увагу й Й. Й. Саєвича (нині - заступник начальника Національної академії сухопутних військ імені гетьмана Петра Сагайдачного, кандидат історичних наук, полковник), одна iз статей [7] якого містить скорочений переказ відповідного розділу («Табір полонених українців у Вецлярі») зі згадуваної монографії I. Срібняка [10, с. 93-110] - із запозиченням використаних іï автором джерел (принагідно слід також додати, що наведена в цій статті інформація про табори Раштат і Зальцведель теж має своєю першоосновою книгу «Полонені українці в АвстроУгорщині та Німеччині (1914-1920 рр.)» [10, c. 72-92, 111-129]*. Аналогічні підходи були

\footnotetext{
* Текстуальне зіставлення цієї статті Й. Й. Саєвича 1 монографії І. В. Срібняка буде здійснено в електронному форматі та розміщено на сторінці кафедри всесвітньої історії Київського університету імені Бориса Грінченка в рубриці «Обережно: академітний плагіат!» [aвm.]
} 
застосовані у ще одній статті [5], що звільняс автора цієї публікації від необхідності ії критичного розгляду.

Між тим останнім часом тривас активна наукова розробка обставин перебування полонених українців у Вецлярі, свідченням чого стала публікація кількох статей, які, хоч і стосувалися різних аспектів життедіяльності української таборової громади, містили й розрізнені дані про специфіку роботи освітніх осередків цього табору [11-14].

Джерельною основою цієї статті стали матеріали Центрального державного apxiву вищих органів влади та управління України (ЦДАВО України, м. Київ) та Центрального державного історичного архіву (ЦДІА України, м. Львів). Важливе значення для відтворення динаміки розвитку просвітницької роботи у Вецлярі має стаття П. Лисецького [4, с. 36-37], який брав безпосередню участь у налагодженні культурноорганізаційного життя в цьому таборі, що, зрештою. дозволяе віднести цю публікацію до розряду джерел.

Метою дослідження є реконструкція процесу діяльності народної штколи полонених українців зі складу царської армії в таборі Вецляр 3 моменту іiі заснування (вересень 1915 p.) і до квітня 1917 p.

Виклад основного матеріалу дослідження. Після ухвалення рішення про українізацію табору Вецляр (вересень 1915 р.) Берлінська централя Союзу визволення України (СВУ) делегувала сюди своїх представників для налагодження культурноосвітньої роботи. Освіта була одним 3 найефективніших засобів українізації, тому не дивно, що вже в останніх числах цього місяця в таборі постала народна школа, яка була заснована шляхом організації окремого курсу для неграмотних полонених. Одногодинний щоденний курс (провадив народний вчитель полонений Бахір) включав у себе викладання абетки, проведення читань та навчання письму. Викладання в народній школі проводились у спеціальному бараку, який був виділений для цісї мети комендатурою табору. Аби потрапити до школи, школярі повинні були мати перепустку. У перший день на курсах неграмотних зібралося близько 25 полонених, які й розпочали заняття. Як ішлося у звіті про роботу школи, «настрій був гарний, у всіх видно було щире бажання научитися грамоти, пізнати світ» [15, арк. 23].

Вже наступного дня кількість учнів збільшилась, i невдовзі ї число досягло 40 осіб. Але через залякування учнів чорносотенцями мала місце велика плинність кон- тингенту - частина полонених під їх впливом залишала навчання, натомість замість них заняття розпочинали інші таборяни. Восени 1915 р. школу спорадично відвідувало до 100 полонених, з яких 20-25 вчащали до неї регулярно. Вже на другий тиждень роботи курсу для неграмотних полоненим почали викладати «науку рахунків» (вчителі - полонені Юрченко і Ращинський), збільшивши тривалість занять до двох годин [15, арк. 23].

На середину листопада 1915 р. курс для неграмотних був завершений, а його учні (2025 полонених) утворили другий клас школи (вчитель - полонений Деревяженко). У цей час було сформовано й перший клас для новачків (30-35 осіб), у якому викладав вчитель Бахір. Як у першому, так і в другому класах викладалися грамота, рахунки, читання і писання. Крім того, полонені мали можливість прослухати виклади 3 географії (вчителі - полонені Григорович і Полуботок). У цьому форматі навчання в школі тривало до кінця 1915 р., але весь цей час чорносотенні елементи в таборі не припиняли своєї розкладової роботи, наслідком чого стало помітне зменшення кількості учнів [15, арк. 24].

За розпорядженням таборової комендатури кожен учень школи повинен був носити на руці пов'язку з червоного матеріалу з нашитим на неї хрестом, що додатково дратувало таборовий загал (учні школи звільнялися від робіт у таборі та користувалися правом вільного пересування між блоками в таборі). У лютому 1916 р., коли «чорна сотня» наважилася на відкритий виступ у таборовому театрі [12, с. 112-113], школу відвідували лише «найвідважніші ученики, бо залякування 3 боку темних елементів дійшло до найвищої точки». Чорносотенці не зупинялись і перед застосуванням фізичного насильства стосовно поодиноких учнів [15, арк. 24].

Попри такий пресинг «чорної сотні» школа у цей час була реорганізована у трикласну, але учнів у ній було досить мало (до 60 осіб), так що фактично працювали лише два класи. Навесні кількість учнів зменшалася до 25 , причиною чого стало перенесення акцентів 3 просвітницької на національноорганізаційну роботу [15, арк. 24-25]. Намагаючись привернути до занять у школі полонених з початковою освітою, 323 травня $1916 \mathrm{p}$. було розпочато викладання в межах «Людового університету» (з історії України, «державно-політичних наук», української літератури, кооперації, суспільно-політичних наук, будови світу, медицини, української справи), а також земельного господарства та аграрного питання [16, арк. 29; 17, арк. 3]. 
Фактично «Людовий університет» став окремим (четвертим) класом школи, але фактичне суміщення занять у школі та новоствореному класі так і не привернуло до школи якоїсь значної кількості нових учнів.

Влітку 1916 р. заняття в школі були перервані у зв'язку із сільськогосподарськими роботами, до яких було залучено переважну більшість полонених. Водночас українська організація табору вжила заходів для підвищення кваліфікації вчителів організувавши проведення трьох «учительських конференцій». В їх рамках було виголошено три доповіді («Про модерний спосіб навчання в початковій школі» П. Лисецького, «Загальні методичні уваги до навчання географії» О. Терлецького $\mathrm{i}$ «Метод навчання природознавства» М. Кордуби), які підвищили загальні професійні компетенції таборових вчителів [15, арк. 26].

25 листопада 1916 р. заняття в школі були відновлені, причому вже за кілька днів після відкриття школи в ній навчалося до 200 постійних учнів та 100 «курсистів» («вільних слухачів»). 3 огляду на таке збільшення кількості бажаючих навчатися в шшолі - в ній було створено три класи, призначені для постійних учнів. Іхні прізвища вносилися до загального списку школи та класних журналів, вони отримували посвідчення на звільнення від таборових робіт та мали право користуватися всім навчальним приладлям в школі. Заняття відбувались щоденно протягом трьох годин під проводом вчителів Якубчука, Деревяженка, Ярмоленка і Ступака. Фактично четвертим класом школи були «курси вільних слухачів», у рамках яких полоненим викладались основи бухгалтерії, «купецької i банкової арифметики», географіï, біології, літератури, рідної мови, політичної економії, історії, німецької мови. Викладання всієї номенклатури дисциплін забезпечувалося силами членів просвітнього відділу СВУ в таборі (Б. Лепким, О. Терлецьким, В. Пачовським, М. Кордубою і П. Лисецьким) [15, арк. 26].

Таке збільшення кількості учнів школи засвідчило ріпучу переміну настроїв таборян, які вже не вбачали в 11 існуванні якоїсь «політики». До того ж керівництво школи докладало «всіх можливих старань, аби зацікавити людей своєю справою». Нарешті, самі полонені після кількамісячної перерви «зголодніли на науку», тому «потреба знання взяла своє, і люди стали тверезіше судити про значіннє шкільних записів» [15, арк. 27].

3 огляду на постійне збільшення числа учнів у школі, просвітній відділ СВУ докладав зусиль для розширення континген- ту вчителів - і вже на початку грудня 1916 p. «учительський гурток» школи поповнився вчителями Чернухою, Бовкуном, Головачем, Якубовим, Ратушенком і Ращинським. Школа була в чергове реорганізована - в і1і складі було створено четвертий клас для постійних учнів, яким стали викладатися додаткові предмети (історія, географія, природознавство, геометрія). Відповідно курси «вільних слухачів» набули статусу 5-го класу, номенклатура дисциплін якого була розширена шляхом запровадження викладів 3 гігієни, «національної економії», землеустрою та ін. Також було ухвалено рішення про розділення на два курси німецької мови (початковий для новачків, i «вищий» - для «тих учнів, які уже придбали початкові знання» 3 неї). Викладачами німецької мови були затверджені П. Лисецький (початковий курс), В. Пачовський і М. Кордуба [15, арк. 27-28].

У грудні 1916 р. керівництвом школи було запроваджено важливі зміни, які стосувались функціонування класів. Кожен клас отримав свого господаря, до обов'язків якого належав догляд за дорученим йому класом, забезпечення учнів підручниками та приладдям для навчання, ведення класного журналу, чергування та заміна відсутніх через хворобу вчителів. Крім того, було призначено «запасних вчителів» (Бахір, Козицький, Черчик, Гребеник, Андріюк і Смець). Також було вирішено розробити «регулямин» та програму діяльності гуртка вчителів школи, який набув на цей момент й власної назви («Учительський гурток Просвітньої громади імені М. Драгоманова») [Там само].

Наприкінці листопада 1916 р. почали діяти курси для неписьменних у таборовому лазареті (спочатку там було лише три учні, але станом на кінець року іх кількість збільшилася до 12 таборян). Крім викладання стандартного блоку дисциплін (як у народній школі), для хворих у лазареті проводилися й загальні читання (уривки з творів Т. Шевченка, гумористичні вірші С. Руданського тощо). Також були враховані й освітні потреби інвалідів, які перебували в окремому бараку та не могли через свій фізичний стан відвідувати заняття в таборовій школі. 320 учнями-інвалідами працювали вчителі Бортняк, Деревяженко, Гордієнко, Б. Лепкий і В. Пачовський [15, арк. 28].

На початку 1917 р. внаслідок напливу до школи значної кількості учнів перший клас школи було поділено на два відділи («а» i «б»), де полонених вчили «науці грамоти», «рахункам» (арифметиці), співу, читанню і німецькій мові (початковий курс) шість 
днів на тиждень. У другому класі полонені разом 3 поглибленням своїх знань 3 означених предметів вивчали українську мову й проходили «вищций курс німецької мови». У 3-4-х класах до вказаних предметів додавалися природознавство, географія та історія України, геометрія, всесвітня історія, хімія і фізика [17, арк. 5]. Для тих, хто скінчив школу, діяв п'ятий клас, в якому таборянам, крім вже згадуваних предметів, викладались політична економія, фізика, біологія, геологія, гігієна та ін. Загальна кількість учнів у чотирьох класах становила на цей час 200 осіб, крім того ще 50-100 таборян відвідувало 5-й клас. Для бажаючих діяли курси німецької мови[2, с. 4].

Навчання в школі тривало до кінця березня 1917 р., коли воно було знову припинено через від'їзд полонених на сільськогосподарські роботи. Протягом свосї 13-и місячної діяльності (лютий 1916 - березень 1917 рр.) таборова «Народна школа» здійснила випуск 2323 учнів, ще 560-600 осіб вивчилися грамоті (засвоїли вміння читати й писати українською мовою), скінчивши тільки перші класи школи $[4$, с. 99]. Це мало великий вплив на робітничі команди, бо випускники школи у свою чергу також розпочинали навчати своїх товаришів грамоті, вже перебуваючи поза табором.

Ці цифри свідчили про ефективність діяльності школи, хоча іï керівництво було свідоме недоліків у роботі пколи, зокрема, як йшлося в короткому історичному нарисі 3 iі діяльності, «не було в ній ні переходних, ні випускних іспитів для учнів, часто мінявся учительський персонал, в иншाий учитель школи до того иноді й не відповідав своєму призначенню, бо не один 3 них не був фаховим учителем». До того ж «ріжні ситуації в таборі часто перешкоджали людям ходити акуратно (тут: регулярно - aвm.) до школи, а це дуже зле відбивалося на систематичному ведення іï. Попри всі негаразди діяльність таборової народної пшколи дозволила суттєво активізувати просвітницьку роботу серед полонених, спромоглася «піднести рівень грамотности нашого народу», залишившти «помітний слід по собі» [15, арк. 29].

Висновки. Отже, із самого початку свого існування школа виступала дісвим інструментом українізації полонених, але ii впливи протягом вересня 1915 - жовтня 1916 рр. були обмеженими через потужну антиукраїнську обструкцію 3 боку чорносотенців та малоросів, присутність яких у таборі розтягнулася на довгі місяці. Тим не менште, вчительський склад школи не припиняв своєї роботи, роблячи свій внесок у формування національної свідомості учнів. Восени 1916 р. зусилля українських гуртків та установ (включаючи народну школу) набули кумулятивного ефекту - більшість таборян засвоїла проукраїнські погляди та почала активно долучатися до роботи таборових культурно-освітніх осередків.

Після цього народна школа стала «центром тяжіння» в масштабах усього табору, кількість ії учнів невпинно зростала, бо останні збагнули конечну потребу власної освіти. Усе більше і більше полонених хотіли позбутися своєї неграмотності, а крім того, здобути й додаткову суму знань 3 різних ділянок знань, які їм пропонувала школа. Українська організація табору подбала про забезпеченість школи вчительським складом 3 числа самих полонених, разом 3 тим дуже важливою була й участь у викладацькій роботі цивільних членів просвітнього відділу СВУ - просвітян 3 гімназійною або університетською освітою (Б. Лепкого, О. Терлецького, В. Пачовського, М. Кордуби і П. Лисецького), завдяки яким таборяни мали можливість пізнати всю красу українського красного письменства, а також здобути знання з історії та географії України, рахівництва, природознавства, німецької мови, а також засвоїти основи точних наук (геометрії, хімії та фізики).

Таким чином, завдяки народній школі полонені не тільки здобували грамоту, вміння писати й рахувати, але разом 3 тим в ix свідомості відбувалися незворотні зміни, що були зумовлені національним характером шшколи та патріотично-державницькою позицією іі вчителів. Скінчивши школу, і1 колишні учні вже нерозривно пов'язували себе з Україною, будучи готовими поділитися своїм багажем знань задля ствердження національних ідеалів у середовищі полонених українців.

\section{Бібліографічні посилання}

1. Бїлик Н. Б. С. Лепкий - діяч Союзу визволення України. Тернопільський міський осередок Наукового товариства їм. Шевченка: зб. праць. Тернопіль, 2006. Т. 2: Національно-визвольні змагання українського народу у XX ст. С. 24-44.
2. В. Г. Народна пккола. Просвітній Листок. Вецляр, 17 грудня 1916. Ч. 37. С. 4.

3. Кривошеєва Л. М. Національно-просвітня діяльність Союзу визволення України в таборах військовополонених українців (1914-1918рp.): дис. канд. іст. 
наук: 07.00.01 - Історія України. Запорізький національний університет. Запоріжжя, 2009.

4. Лисецький П. Як виглядає просвітноорганізаційне житте в українськім таборі у Вецлярі. Вістник політики, літератури й життя. Відень, 20 січня 1918. Ч. 3 (186). С. 95-99.

5. Мозохіна $Є .3$ історії розвитку освітньої справи у таборі полонених українщів Вецляр (Німеччина) у 1915-1917 pp. Вісник Чернігівського начіонального педагогічного університету. Серія: Історичні науки. Чернігів, 2014. Вип. 123. С. 191-196. C. 8 .

6. Просвітній листок. Вецляр, 1 березня 1916. Ч. 5.

7. Саєвич Й. Й. Українські віћськовополонені в таборах Німеччини: фінансово-господарська і культурно-освітня діяльність (1914-1918 рр.). Вісник Начіонального університету «Львівська політехніка». 2006. № 571: Держава та армія. С. 244-250.

8. Срібняк I. 3 історії культурно-просвітницької діяльності полонених українців у таборі Вецляр (Німетчина) в 1915 р. Етноначіональний розвиток в Україні та стан української етнічності в діаспорі: сутність, реаліl конфліктності, проблеми та прогнози на порозі XXI століття: Тези п'ятої Міжнародної науково-практичної конференції (Київ - Чернівці, 22-25 травня 1997 р.). Київ; Чернівці, 1997. Ч. 2. С. 441-443.

9. Срібняк І. Табір полонених українців у Вецлярі (Німеччина) у 1915-1917 рр. Вісник Київського державного лінгвістичного університету. Серія «Історія, економіка, філософія». К., 1998. Вип. 2. С. 38-57.

10. Срібняк I. Полонені украйнщі в Австро-Угорщині та Німеччині (1914-1920 рр.). К., 1999. С. 93-110.

11. Срібняк I. Громада полонених вояків-українців царської армії у таборі Вецляр, Німеччина (вересень 1915 - грудень 1916 рр.): за матеріалами ЦДАВО України. Емінак. Київ; Миколаїв, 2020. № 3 (31). C. $217-233$.

12. Срібняк I., Срібняк М., Шнайдер В. Український аматорський театр у таборі полонених українців Вец- ляр, Німеччина (осінь 1915 -зима 1917 рр.). Свропейські історичні студіï. К., 2020. № 17. С. 108-154.

13. Срібняк I., Шнайдер В. Формування світогляду полонених українців засобами друкованого слова: національно-виховна місія часопису «Просвітній Листок» у таборі Вецляр, Німеччина (1916 р.). Синопсис: текст, контекст, медіа. К., 2020. Т. 26. № 3. С. 90-97.

14. Срібняк I., Шнайдер В. Часопис «Просвітній Листок» як джерело для реконструкції історії розвитку української громади у таборі Вецляр, Німеччина (1916 р.). Київські історичні студї. К., 2020. № 2 (11). С. 50-59.

15. Центральний державний архів вищих органів влади України (ШДАВО України). Ф. 4382. Оп. 1. Cпр.1.

16. ЦДАВО України. Ф. 4382. Оп. 1. Спр. 30.

17. Центральний державний історичний архів України (м. Львів). Ф. 309. Оп. 1. Спр. 2634.

18. Golczewski Frank. Deutsche und Ukrainer: 1914 1939. Paderborn: Ferdinand Schöningh Verlag, 2010. S. $108-127$.

19. Jung Irene, Wiedl Wolfgang. Ein «besonderes» Lager für Ukrainer. Zwischen Propaganda und Alltagsnot. Wetzlar und der Erste Weltkrieg 1914-1918.Neustadt an der Aisch, 2016. S. 262-282.

20. Rehmer C. Das Ukrainerlager Wetzlar-Büblingshausen (1915-1918). Ein besonderes Lager? Mitteilungen des Wetzlarer Geschichtsvereins, 1994. Heft 37. S. 77-116.

21. Rehmer C. «Revolutiomierungspolitik» und Ukrainer-Lager. Die Ukraine im Blickfeld deutscher Interessen. Ende des 19. Jahrhunderts bis 1917/18. Frankfurt a. M. u. a., 1997. S. 245-280.

22. Runzheimer J. «...Damit alle an uns erinnert werden»! Das ukrainische Gefangenenlager in Wetzlar. Heimat an Lahn und Dill. 1994. Bd. 284. S. 2-3.

23. Runzheimer Jürgen. Film als historische Quelle. Das ukrainische Kriegsgefangenenlager in Wetzlar. Claudia Weidemann und Rudolf Worschech: Kamera. Oskar Barnack. Frühe Filme aus Wetzlar und Umgebung, Frankfurt am Main, 2002. S. 25-28.

\section{References}

1. Bilyk N. (2006). B. S. Lepkyy - diyach Soyuzu vyzvolennya Ukrayiny [B. S. Lepky - the figure of Umion for the Liberation of Ukraine] Ternopil's'kyy mis'kyy oseredok Naukovoho tovarystva im. Shevchenka: zb. Prats. Ternopil, vol. 2: Natsional'no-vyzvol'ni zmahannya ukrayins'koho narodu u XX st., pp. 24-44 (in Ukrainian).

2. V. H. (1916). Narodna shkola [Public school]. Prosvitniy Lystok. Vetslyar, no. 37 (m Ukrainian).

3. Kryvosheieva L. (2009). Natsionalno-prosvitnia diialnist Soiuzu vyzvolennia Ukrainy $v$ taborakh viyskovopolonenykh ukraintsiv (1914-1918 rr.) (NationalEducational Activity of the Union of Liberation of Ukraine in the Camps of Prisoners of War of Ukrainians (19141918)]. Zaporizkyi natsionalnyi universytet. Zaporizhzhia (in Ukrainian).

4. Lysets'kyy P. (1918). Yak vyhlyadaye prosvitno-orhanizatsiyne zhyttye $v$ ukrayins'kim tabori $u$ Vetslya$r i$ [What is the educational and organizational life in the Ukrainian camp in Wetzlar]. Vistnyk polityky, literatury y zhyttya. Viden', vol. 3 (186), pp. 95-99 (in Ukrainian).

5. Mozokhina Ye (2014). Z istorii rozvytku osvitnoi spravy u tabori polonenykh ukraintsiv Vetsliar (Nimechchyna) u 1915-1917 rr. From the history of the development of educational work in the camp of Ukrainian prisoners Wetzlar (Germany) in $1915-1917$ [From the history of the development of educational work in the camp of Ukrainian prisoners Wetzlar (Germany) in 1915-1917]. Bulletin of the Chernihiv National Pedagogical University, series: Historical Sciences, Chernihiv, issue 123, pp. 191196 (in Ukrainian).

6. Prosvitniy lystok (1916). Vetslyar, vol. 5, p. 8 (in Ukrainian).

7. Saievych Y. Y. (2006). Ukrainski viiskovopoloneni v taborakh Nimechchyny: finansovo-hospodarska i kulturnoosvitnia diialnist (1914-1918 rr.). [Ukrainian prisoners of war in German camps: financial, economic, cultural and educational activities (1914-1918)]. Bulletin of the Lviv Polytechnic National University, no 571: State and Army, pp. 244-250 [in Ukrainian].

8. Sribnyak I.(1997).Zistoriyikul'turno-prosvitnyts'koyi diyal'nosti polonenykh ukrayintsiv u tabori Vetslyar (Nimechchyna) $v 1915 \mathrm{r}$. [From the history of cultural and educational activities of captured Ukrainians in the camp Wetzlar (Germany) in 1915]. Etnonatsional'nyy rozvytok $v$ Ukrayini ta stan ukrayins'koyi etnichnosti $v$ diaspori: sutnist', realiyi konfliktnosti, problemy ta prohnozy na porozi XXI stolittya: Tezy p'yatoyi Mizhnarodnoyi naukovo-praktychnoyi konf. (Kyiv-Chernivtsi, 22-25 
travnya 1997 r.). Kyiv; Chernivtsi, vol. 2, pp. 441-443 (in Ukrainian).

9. Sribnyak I. (1998). Tabir polonenykh ukrayintsiv u Vetslyari (Nimechchyna) u 1915-1917 rr. [Camp of Prisoners Ukrainians in Wetzlar (Germany) in 19151917]. Visnyk Kyyivs'koho derzhavnoho linhvistychnoho universytetu. Seriya «Istoriya, ekonomika, filosofiya». Kyiv, issue 2, pp. 38-57 (in Ukrainian).

10. Sribnyak, I. (1999). Poloneni ukrayintsi v AvstroUhorshchyni ta Nimechchyni (1914-1920 rr.) [Prisoners Ukrainians in Austria-Hungary and Germany (1914 1920)]. Kyiv, pp. 93-110 (in Ukrainian).

11. Sribnyak I. (2020). Hromada polonenykh voyakiv-ukrayintsiv tsars'koyi armiyi u tabori Vetslyar, Nimechchyna (veresen' 1915 - hruden' 1916 rr.): za materialamy TSDAVO Ukrayiny [Community of captured Ukrainian soldiers of the tsarist army in the camp Wetzlar, Germany (September 1915 - December 1916): according to the materials of the Central State Archives of Ukraine]. Eminak. Kyiv; Mykolayiv, no 3 (31), pp. 217-233 (in Ukrainian).

12. Sribnyak I., Sribnyak M. \& Shnayder V. (2020). Ukrayins'kyy amators'kyy teatr $u$ tabori polonenykh ukrayintsiv Vetslyar, Nimechchyna (osin' 1915 - zyma 1917 rr.) [Ukrainian amateur theater in the camp of captured Ukrainians Wetzlar, Germany (autumn 1915 winter 1917)]. Yevropeys'ki istorychni studiyi, No 17, pp. 108-154 (in Ukrainian).

13. Sribnyak I. \& Shnayder, V. (2020). Formuvannya svitohlyadu polonenykh ukrayintsiv zasobamy drukovanoho slova: natsional'no-vykhovna misiya chasopysu "Prosvitniy Lystok» u tabori Vetslyar, Nimechchyna (1916 r.) [Formation of the worldview of captured Ukrainians by means of the printed word: national-educational mission of the magazine «Enlightenment Leaf» in the camp Wetzlar, Germany (1916)]. Synopsys: tekst, kontekst, media, vol. 26, No 3, pp. 90-97 (in Ukrainian).
14. Sribnyak I. \& Shnayder V. (2020). Chasopys «Prosvitniy Lystok» yak dzherelo dlya rekonstruktsiyi istoriyi rozvytku ukrayins'koyi hromady u tabori Vetslyar, Nimechchyna $\left(\begin{array}{ll}1916 & \text { r.) }\end{array}\right.$ [Prosvitniy Listok magazine as a source for the reconstruction of the history of the development of the Ukrainian community in the Wetzlar camp, Germany (1916)]. Kyyivs'ki istorychni studiyi, no 2 (11), pp. 50-59 (in Ukrainian).

15. Central State Archives of Supreme Authorities and Government of Ukraine (CDAVO of Ukraine, Kyiv). $F$. 4382. Inventory 1 . File 1 .

16. CDAVO of Ukraine. F. 4382. Inventory 1. File 30.

17. Central State Historical Archive (CSHA, Lviv). F. 309. Inv. 1. File 2634.

18. Golczewski F. (2010). Deutsche und Ukrainer: 1914-1939. Paderborn: Ferdinand Schöningh Verlag, S. $108-127$.

19. Jung, I. \& Wiedl, W. (2016). Ein «besonderes» Lager für Ukrainer Zwischen Propaganda und Alltagsnot. Wetzlar und der Erste Weltkrieg 1914-1918. Neustadt an der Aisch, S. 262-282.

20. Rehmer C. (1994). Das Ukrainerlager WetzlarBüblingshausen (1915-1918). Ein besonderes Lager? Mitteilungen des Wetzlarer Geschichtsvereins, vol. 37, S. 77-116.

21. Rehmer C. (1997). «Revolutionierungspolitik» und Ukrainer-Lager. Die Ukraine im Blickfeld deutscher Interessen. Ende des 19. Jahrhunderts bis 1917/18. Frankfurt a. M. u. a., S. 245-280.

20. Runzheimer J. (1994). «...Damit alle an uns erinnert werden»! Das ukrainische Gefangenenlager in Wetzlar Heimat an Lahn und Dill, B. 284, S. 2-3.

23. Runzheimer J. (2002). Film als historische Quelle. Das ukrainische Kriegsgefangenenlager in Wetzlar Claudia Weidemann und Rudolf Worschech: Kamera. Oskar Barnack. Frühe Filme aus Wetzlar und Umgebung. Frankfurt am Main, S. 25-28. 